\title{
Reactions of Perennial Grain Accessions to Four Major Cereal Pathogens of the Great Plains
}

C. M. Cox and K. A. Garrett, Department of Plant Pathology, Kansas State University, Manhattan 66506; T. S. Cox, The Land Institute, 2440 E. Water Well Rd., Salina, KS 67401; W. W. Bockus, Department of Plant Pathology, Kansas State University, Manhattan 66506; and T. Peters, Peters Seed and Research, P.O. Box 1472, Myrtle Creek, OR 97457

\begin{abstract}
Cox, C. M., Garrett, K. A., Cox, T. S., Bockus, W. W., and Peters, T. 2005. Reactions of perennial grain accessions to four major cereal pathogens of the Great Plains. Plant Dis. 89:12351240 .

Methods of disease management used in annual grain crops, especially cultural practices designed to disrupt the disease cycle of a particular pathogen, will not necessarily be applicable to perennial grain crops. Resistance to multiple pathogens, therefore, will clearly be important in disease management. The objective of this research was to evaluate disease resistance in 10 perennial grain accessions (one to two accessions of each: perennial wheat (Thinopyrum sp. $\times$ Triticum aestivum), intermediate wheatgrass (Thinopyrum intermedium), perennial rye (Secale montanum), hexaploid triticale (Triticum turgidum $\times$ S. montanum), octoploid triticale (Triticum aestivum $\times$ S. montanum), tetraploid perennial rye $($ Secale cereale $\times S$. montanum), and tall wheatgrass (Thinopyrum ponticum)) to tan spot (caused by Pyrenophora tritici-repentis), take-all (caused by Gaeumannomyces graminis var. tritici), wheat streak mosaic, and barley yellow dwarf, four important diseases of the Great Plains. Several of the grasses were resistant to tan spot, barley yellow dwarf, and wheat streak mosaic. Indeed, the wild grasses and perennial donors T. intermedium (including BFPMC1), T. ponticum, and S. montanum, in addition to Permontra, a tetraploid perennial rye, were highly resistant to all three diseases. Additionally, the remaining grasses tested were also more resistant to tan spot than the susceptible wheat control. However, none of the 10 grass accessions appeared highly resistant to take-all, and substantial losses in biomass were observed, although such effects may be moderated under field conditions due to the potential for take-all decline in perennial plantings.
\end{abstract}

Problems associated with annual grain agriculture, such as soil erosion and water and air pollution, indicate that reliance on annual grain production is a fundamental problem of current agricultural practice (23). Annual plant roots are less efficient micromanagers of water, soil, and soil nutrients than their perennial counterparts, resulting in nutrient and pesticide contamination of water sources even when best management practices are employed $(12,22,32,35,36)$. Successful production of perennial, herbaceous grains could profoundly reduce these adverse effects of agriculture $(10,11,29,33)$.

Methods of disease management used in annual grain crops, especially cultural practices designed to disrupt the disease cycle of a particular pathogen, such as short rotations, tillage, and delayed fall planting, will not necessarily be applicable

Corresponding author: K. A. Garrett

E-mail: kgarrett@ksu.edu

Current address of C. M. Cox: The Land Institute, 2440 E. Water Well Rd., Salina, KS 67401.

Accepted for publication 28 June 2005.

DOI: 10.1094/PD-89-1235

(C) 2005 The American Phytopathological Society to perennial grain crops. Practices such as deployment of crops in mixtures, intercrops, or polycultures may be an important component in perennial grain agriculture $(4,7,8,17,18,30,46)$. But whether perennials are mixed within polycultures or uniform in monocultures, resistance to a set of locally important cereal diseases will be an essential managerial component $(3,7)$.

Wheatgrasses (Thinopyrum spp.), the perennial donors in perennial wheat breeding programs, are resistant to many of the diseases that infect annual wheat, including wheat streak mosaic (WSM), stripe rust, leaf rust, and barley yellow dwarf (BYD) $(14,15,24,26)$. In greenhouse experiments, several perennial wheat germ plasm lines (Thinopyrum spp. $\times$ Triticum aestivum hybrids) demonstrated high levels of resistance to Cephalosporium stripe (caused by Cephalosporium gramineum Nisikado \& Ikata), eyespot (caused by Tapesia yallundae Wallwork \& Spooner and T. acuformis (Boerma, Pieters \& Hamers) Crous (anamorph Pseudocercosporella herpotrichoides (Fron.) Deighton var. herpotrichoides and var. acuformis, respectively)), and WSM, three important wheat diseases of the Pacific Northwest region of the United States where perennial wheat is also being considered $(9,40)$.
Tan spot and take-all are important residue- and soilborne diseases of wheat, caused by Pyrenophora tritici-repentis (Died.) Drechs. and Gaeumannomyces graminis (Sacc.) Arx \& D. Olivier var. tritici J. Walker, respectively. P. tritici-repentis causes leaf lesions initiated by wind- and splashed-dispersed ascospores, or winddispersed conidia, while G. graminis var. tritici infects roots and crowns and can kill entire plants (45). Perennial crowns and persistent residue in the soil could potentially serve as a reservoir for these pathogens as well as for other pathogens that share similar life histories.

By virtue of regrowth after harvest, perennial plants emerge and assimilate carbon well before adjacent, newly sown annual relatives (11). This provides more opportunities for infection by viruses that rely on the "green bridge" of susceptible hosts, such as Barley yellow dwarf virus (BYDV) and Wheat streak mosaic virus (WSMV) (45). Combined resistance to WSM and BYD, therefore, as well as to tan spot and take-all, is desirable for longevity and successful production of perennial grains in this region.

The objective of this research was to evaluate disease resistance in 10 perennial grain accessions to tan spot, take-all, wheat streak mosaic, and barley yellow dwarf, four important diseases of the central Great Plains of the United States.

\section{MATERIALS AND METHODS}

Plant species and accessions. In each of the experiments, there were 10 accessions of perennial grasses (Table 1) obtained from Peters Seed \& Research, Myrtle Creek, OR (PSR-1, PSR-2), USDANRCS Big Flats Plants Materials Center (BFPMC1), the Wheat Genetics Resource Center, Manhattan, KS (TA 12252), R. Reimann-Philipp, Ahrensburg, Germany (Permontra), USDA-ARS Western Region Plant Introduction Center (PI 223231 and PI 502359), and USDA-ARS Small Grains Western Region Plant Introduction Center (PI 386419, PI 386150, PI 386156). These plant accessions are included as part of a larger initial evaluation of genotypes for traits of adaptation to the central Great Plains and represent a range of candidate species for domestication and/or breeding of perennial grain crops. Seven of these accessions have displayed perennial 
growth habit in other geographical regions. It is not yet known whether PI 386419, PI 386150, and PI 386156, each of which had one perennial parent, have any perennial tendency.

Winter wheat cvs. Karl 92 and TAM 105 were included as resistant and susceptible tan spot controls, respectively; cvs. Coker 9663 and Larned were included as BYD resistant and susceptible checks, respectively; cv. TAM 107 was used as a susceptible control in take-all experiments; and cv. 2180 was used for both WSMsusceptible and mock-inoculated controls (Table 1). Wheat seed was obtained from the Department of Agronomy Foundation Seed Center, Kansas State University.

Fungal inoculation and disease evaluation. Plants screened for resistance to tan spot and take-all were grown in the greenhouse under ambient light conditions and an average temperature range of $68^{\circ} \mathrm{F}$ to $78^{\circ} \mathrm{F}$. All plants were grown from seed in $2.5 \times 12.5 \mathrm{~cm}$ plastic cones and fertilized with Peter's 20:20:20 every 2 weeks postemergence. In the two tan spot experiments, individual seeds were sown into a 50:50 sterilized soil and sand mix. Ten cones of each line composed an experimental unit, and experimental units were replicated four times in a randomized complete block design. In the two take-all experiments, individual seeds were sown in vermiculite. For each line, two sets of 10 cones each were placed side by side in vertical rows to compose an experimental unit, and experimental units were replicated four times in a randomized complete block design. One row of each pair of rows per line was randomly selected for inoculation, while the other row within the pair was not inoculated.

Tan spot (Pyrenophora tritici-repentis). Inoculation procedures were based on methods described by Raymond et al. (37). Four different isolates of $P$. tritici-repentis, race 1 (5), from naturally infected hard red winter wheat in Kansas, were grown on $1 / 4$ strength potato dextrose agar in petri dishes for approximately 1 week in continuous light at room temperature. Mycelial plugs were then removed and inoculated onto plates of V8 agar and cultured in the dark for 4 to 5 days at $24^{\circ} \mathrm{C}$. Aerial hyphae were flattened around the perimeter with a sterile, bent-glass rod, and plates were placed at 15 to $24^{\circ} \mathrm{C}$ for 12 to $24 \mathrm{~h}$ in continuous light followed by 16 to $24 \mathrm{~h}$ in the dark at $4^{\circ} \mathrm{C}$. Conidiophores and conidia are produced during the light and dark cycles, respectively. Conidia were harvested by rinsing plates with distilled water, gently scraping colonies with a bent metal scraper, and pouring the rinse through a layer of cheesecloth. Final spore concentrations were approximately 7,000 per ml.

Four weeks after planting, approximately 245,000 spores per flat of 100 cones were sprayed on plant surfaces using a DeVilbiss atomizer at $69 \mathrm{kPa}$. Plants were then placed into a mist chamber for $48 \mathrm{~h}$ at $22 \pm 5^{\circ} \mathrm{C}$. After misting, plants were again placed in the greenhouse under the previous conditions, and leaves were rated for percent leaf area showing symptoms of tan spot (disease severity) 6 days later.

Take-all (Gaeumannomyces graminis var. tritici). To produce inoculum, $150 \mathrm{ml}$ of distilled water was added to $140 \mathrm{~g}$ of whole oat kernels in 1-liter glass jars. Jars were capped with perforated, cottonplugged lids and shaken to moisten the oats. Jars were then autoclaved and allowed to cool under a laminar-flow hood. Three to four plugs (each 100 to $400 \mathrm{~mm}^{2}$ ) of mycelium growing on $1 / 4$ strength PDA were buried in the oats and incubated at room temperature. Jars were periodically shaken to prevent kernels and mycelium from clumping. After kernels became sufficiently blackened by mycelium (2 to 3 weeks), kernels were spread out on tarps to air dry. Dried kernels were stored at $4^{\circ} \mathrm{C}$ prior to use. At planting, three inoculated

Table 1. Perennial grain accessions tested for resistance to tan spot, take-all, wheat streak mosaic, and/or barley yellow dwarf, along with susceptible and resistant annual wheat cultivars included in experiments as checks

\begin{tabular}{|c|c|}
\hline Entry & Common name (species or description) \\
\hline PSR-1 & Perennial wheat (Thinopyrum $\mathrm{sp} . \times$ Triticum aestivum) \\
\hline PSR-2 & Perennial wheat (Thinopyrum $\mathrm{sp} . \times$ Triticum aestivum) \\
\hline BFPMC1 & Intermediate wheatgrass (Thinopyrum intermedium) \\
\hline TA 12252 & Perennial rye (Secale montanum) \\
\hline PI 386419 & Hexaploid triticale (Triticum turgidum $\times S$. montanum) \\
\hline PI 386150 & Octoploid triticale (Triticum aestivum $\times S$. montanum) \\
\hline PI 386156 & Hexaploid triticale (Triticum turgidum $\times S$. montanum) \\
\hline Permontra & Tetraploid perennial rye (Secale cereale $\times S$. montanum) \\
\hline PI 223231 & Intermediate wheatgrass (Thinopyrum intermedium) \\
\hline PI 502359 & Tall wheatgrass (Thinopyrum ponticum) \\
\hline \multicolumn{2}{|l|}{ Wheat controls } \\
\hline Karl 92 & Winter wheat (Triticum aestivum), tan spot resistant \\
\hline TAM 105 & Winter wheat (Triticum aestivum), tan spot susceptible \\
\hline TAM 107 & Winter wheat (Triticum aestivum), take-all susceptible \\
\hline Coker 9663 & Winter wheat (Triticum aestivum), BYD resistant \\
\hline Larned & Winter wheat (Triticum aestivum), BYD susceptible \\
\hline 2180 & Winter wheat (Triticum aestivum), WSM susceptible \\
\hline
\end{tabular}

kernels were placed approximately $2.5 \mathrm{~cm}$ below the soil line within inoculated cones, $1.0 \mathrm{~cm}$ below the seed. Seeds were positioned in the same manner within uninoculated cones, but without the kernels. After 6 weeks, the fresh weight of all plants was measured in order to compare the biomass of inoculated versus uninoculated plants.

Viral inoculation and disease evaluation. Barley yellow dwarf. Field testing of accessions for resistance to BYD was conducted in Chase silty clay loam $(\mathrm{pH}=6.5)$ at the Plant Pathology Research Farm near Manhattan, KS, where epidemics of BYD are common. The experimental design was a randomized complete block with five blocks. Plots were single rows $2.3 \mathrm{~m}$ long with $0.5-\mathrm{m}$ row spacing in all directions and were sown 18 September 2003 and 17 September 2004. Plots were sown 2 weeks earlier than the optimum planting date for wheat in this region, in order to promote BYDV infection. Virus inoculation occurred from infestations by naturally occurring aphid vectors. The percent plants showing leaf symptoms of BYD was visually estimated for each plot on 15 May and 30 May in 2003, and on 20 May and 28 May in 2004, corresponding to soft dough and hard dough stages of wheat, respectively.

Wheat streak mosaic. Five seeds per entry were each sown into a 50:50 sterilized soil and sand mix in $10-\mathrm{cm}$ pots. Pots were arranged in randomized complete blocks and replicated five times. Prior to inoculation, plants were thinned to three per pot. Experiments were conducted in a growth chamber at a constant temperature of $27^{\circ} \mathrm{C}$ and a 12-h photoperiod. Certain A. intermedium-wheat translocation lines appear resistant to WSM below $25^{\circ} \mathrm{C}$, but not at higher temperatures $(9,41)$. The higher temperature was used in this study to avoid selection of temperature sensitive resistance that might be less valuable in the field. Inoculum was extracted from infected source plants (wheat cultivar 2180) by grinding young, symptomatic leaves with a mortar and pestle in $0.02 \mathrm{M}$ sodium phosphate buffer (1:10, wt/vol), pH 7.4, and Carborundum powder $(0.01 \mathrm{~g} / \mathrm{ml})$. Test plants were inoculated at the two-leaf stage by sandwiching the second leaf in cheesecloth saturated with inoculum between the thumb and forefinger, and rubbing the blade once from base to tip (27). The third leaf of each plant was inoculated 4 to 7 days after the first inoculation. $\mathrm{Cv}$. 2180 was mock-inoculated with buffer + Carborundum powder for the negative control.

Approximately 2 weeks after the second inoculation, the youngest leaves of all plants in each pot were harvested (inoculated leaves were avoided) and tested for the presence of WSMV by indirect enzyme-linked immunosorbent assay (ELISA) (6). Plants were visually evalu- 
ated for the presence or absence of WSM symptoms prior to harvest. Plant tissue was cut into 1 - to $3-\mathrm{cm}$ pieces, frozen in liquid nitrogen, and ground with a mortar and pestle. Extraction buffer $(10.0 \mathrm{~g}$ of polyvinyl-pyrrolidone and 1.0 liter of PBS [8.0 $\mathrm{g}$ of NaCl, $0.2 \mathrm{~g}$ of $\mathrm{KH}_{2} \mathrm{PO}_{4}, 1.15 \mathrm{~g}$ of $\mathrm{Na}_{2} \mathrm{HPO}_{4}, 0.2 \mathrm{~g}$ of $\mathrm{KCl}$, and 1.0 liter of distilled water, $\mathrm{pH}$ 7.4]) was added (1:10, $\mathrm{wt} / \mathrm{vol})$, and the tissue was further ground until the liquid turned dark green. To individual wells of a 96-well, flat bottom, ELISA plate (Corning Glass Works, Corning, NY), $75 \mu \mathrm{l}$ of coating buffer (1.59 $\mathrm{g}$ of $\mathrm{Na}_{2} \mathrm{CO}_{3}, 2.93 \mathrm{~g}$ of $\mathrm{NaHCO}_{3}, 0.20 \mathrm{~g}$ of $\mathrm{NaN}_{3}, 1.0$ liter of distilled water, $\mathrm{pH}$ 9.6) was added, followed by $25 \mu \mathrm{l}$ of each treatment sample. Plates were incubated at room temperature for $2 \mathrm{~h}$ and then rinsed with ELISA wash (1.0 liter of PBS and 0.5 $\mathrm{ml}$ of Tween 20) three times for $3 \mathrm{~min}$ each. One-hundred microliters of purified anti-WSMV IgG in ELISA buffer ([1:500] $10.0 \mathrm{~g}$ of polyvinyl-pyrrolidone, $2.0 \mathrm{~g}$ of ovalbumin, $0.2 \mathrm{~g}$ of $\mathrm{NaN}_{3}, 0.5 \mathrm{ml}$ of Tween 20, and 1.0 liter of PBS) was added to each well and incubated at room temperature for $2 \mathrm{~h}$, and then washed as described above. Goat anti-rabbit IgG-alkaline phosphatase conjugate (1:2,000 in ELISA buffer; Sigma Chemical Co., St. Louis, MO) was then added to each well and incubated for 30 min, washed as above, and $p$-nitrophenyl phosphate (PNP) (1 tablet/5 ml diethanolamine [97 ml/liter] buffer, $\mathrm{pH} 9.8$ ) was added. Plates were incubated in the light at room temperature for $30 \mathrm{~min}$, and then optical density at $405 \mathrm{~nm}$ was measured with a Molecular Devices E-max microplate reader (Molecular Devices, Menlo Park, CA). The second experiment was modified in that plates were read every 15 min after adding the substrate until absorbance readings in some wells measured above 2.0 (typically at $45 \mathrm{~min}$ ) to increase the clarity of results. Absorbance values below 2.0 are more quantitative and allow a closer examination of virus titer in plants. Additionally, assays were carried out one block at a time so that the timing of applied treatments to each well within a block would be as close to one another as possible. Double wells of each treatment, a carbonate buffer control, a mockinoculated control (healthy 2180), and an inoculated control (2180) were included on each plate. Peripheral wells of all plates remained empty. WSM ELISA readings were considered positive if absorbance readings were at least two times greater than the healthy control in the first experiment, or if they were statistically different from healthy controls in the second experiment.

Statistical analyses. Tan spot, BYD, and take-all severity scores and WSM ELISA absorbance readings were evaluated in an analysis of variance (ANOVA) with means separated by Fisher's protected least significant difference (LSD). Losses due to take- all were calculated for each plant accession as: [(weight of uninoculated plants) (weight of inoculated plants)]/(weight of uninoculated plants). Statistical analyses were not conducted on WSM ELISA absorbance readings from the first experiment due to the qualitative nature of the assay used in that experiment.

\section{RESULTS}

Fungal diseases. Tan spot (Pyrenophora tritici-repentis). As expected, in both experiments the resistant wheat control Karl 92 had significantly $(P<0.05)$ lower tan spot severity than the susceptible control TAM 105 (Table 2). Indeed, severity scores for TAM 105 were nearly $5 \times$ greater than for Karl 92 in the first experiment and $22 \times$ greater in the second experiment.

In the first experiment, all 10 perennial grass entries were more resistant than TAM 105 as evidenced by significantly lower severity values. Six of the 10 grasses were not statistically different from Karl 92 in their responses. One entry (PSR-2) had significantly lower disease severity than Karl 92. The remaining three entries PI 386149, PI 386150, and PI 386156 (Secale montanum-derived triticale accessions) appeared moderately susceptible to tan spot, and severity scores were significantly higher than for Karl 92 and the other seven entries, but lower than for TAM 105.

Tan spot was less severe in the second experiment than in the first experiment, as indicated by reactions of both resistant and susceptible wheat controls. But results were similar to the first experiment in that severity scores for all entries were significantly lower than those for TAM 105. Further, severity scores for seven of the 10 entries were not significantly different from Karl 92. As in the first experiment, tan spot severities for the three triticale

Table 2. Tan spot severity in perennial grass accessions

\begin{tabular}{lcc}
\hline & \multicolumn{2}{c}{ \% Tan spot severity } \\
\cline { 2 - 3 } Entry & Exp. 1 & Exp. 2 \\
\hline PSR-1 & $15.8 \mathrm{def}^{\mathrm{z}}$ & $3.7 \mathrm{e}$ \\
PSR-2 & $2.7 \mathrm{~g}$ & $2.6 \mathrm{e}$ \\
BFPMC1 & $8.5 \mathrm{fg}$ & $2.6 \mathrm{e}$ \\
TA 12252 & $21.3 \mathrm{~d}$ & $2.7 \mathrm{e}$ \\
PI 386149 & $48.4 \mathrm{~b}$ & $18.2 \mathrm{c}$ \\
PI 386150 & $37.8 \mathrm{c}$ & $12.1 \mathrm{~d}$ \\
PI 386156 & $44.6 \mathrm{bc}$ & $30.7 \mathrm{~b}$ \\
Permontra & $19.1 \mathrm{de}$ & $1.2 \mathrm{e}$ \\
PI 223231 & $9.0 \mathrm{fg}$ & $2.9 \mathrm{e}$ \\
PI 502359 & $10.7 \mathrm{efg}$ & $3.2 \mathrm{e}$ \\
Karl 92 (control) & $14.2 \mathrm{def}$ & $2.1 \mathrm{e}$ \\
TAM 105 (control) & $63.4 \mathrm{a}$ & $46.7 \mathrm{a}$ \\
LSD $(P<0.05)$ & 8.4 & 5.8 \\
\hline
\end{tabular}

${ }^{y}$ Percent leaf area showing symptoms of tan spot.

${ }^{\mathrm{z}}$ Values are means of the oldest three leaves per plant, with 10 plants per each of four replications. Entries within a column that do not share a common letter were significantly different in a mean separation test using Fisher's protected LSD $(P<0.05)$. accessions were moderate to high, but significantly lower than those for TAM 105 and higher than those for Karl 92 and the other seven entries.

Take-all (Gaeumannomyces graminis var. tritici). Biomass reductions of 86.6 and $73.8 \%$ were measured on the susceptible wheat cultivar TAM 107 in the first and second experiments, respectively (Table 3 ). In the first experiment, all 10 grasses also suffered substantial reductions in biomass due to take-all, ranging from 60.9 to $97.7 \%$. Despite high losses to take-all, Permontra, PI 386149, and TA 12252 did have significantly less proportional biomass loss due to disease than TAM 107.

Eight of the 10 grasses suffered moderate to severe biomass losses to take-all in the second experiment, ranging from 39.0 to $97.2 \%$. Two of these eight (PI 386149 and PI 386156) suffered significantly less relative biomass loss than TAM 107. The remaining two entries (TA 12252 and Permontra) appeared resistant to take-all in this experiment, as evidenced by biomass losses measuring less than $10 \%$, although their biomass losses in the first experiment, albeit significantly less than TAM 107, were substantially higher.

Viral diseases. Barley yellow dwarf. Moderate infection by BYDV was apparent at both sampling dates during each year of the experiment (Table 4). As expected, plots of the resistant wheat cultivar Coker 9663 had significantly fewer symptomatic plants than the susceptible control Larned at all sampling dates $(P<0.05)$.

In 2003, at the first sampling date, seven of the perennial grasses had severity scores that were not statistically different from

Table 3. Biomass losses to take-all in perennial grass accessions

\begin{tabular}{llc}
\hline & \multicolumn{2}{c}{$\begin{array}{c}\text { Biomass losses } \\
\text { to take-all }\end{array}$} \\
\cline { 2 - 3 } Entry & Exp. 1 & Exp. 2 \\
\hline PSR-1 & $87.9 \mathrm{a}^{\mathrm{z}}$ & $75.3 \mathrm{~b}$ \\
PSR-2 & $94.5 \mathrm{a}$ & $84.2 \mathrm{ab}$ \\
BFPMC1 & $97.7 \mathrm{a}$ & $97.2 \mathrm{a}$ \\
TA 12252 & $62.8 \mathrm{bc}$ & $8.9 \mathrm{~d}$ \\
PI 386149 & $61.5 \mathrm{c}$ & $39.0 \mathrm{c}$ \\
PI 386150 & $78.5 \mathrm{abc}$ & $69.2 \mathrm{bc}$ \\
PI 386156 & $82.9 \mathrm{ab}$ & $51.4 \mathrm{c}$ \\
Permontra & $60.9 \mathrm{c}$ & $9.7 \mathrm{~d}$ \\
PI 223231 & $87.4 \mathrm{a}$ & $80.8 \mathrm{ab}$ \\
PI 502359 & $97.6 \mathrm{a}$ & $91.7 \mathrm{ab}$ \\
TAM 107 (control) & $86.6 \mathrm{a}$ & $73.8 \mathrm{~b}$ \\
LSD $(P<0.05)$ & 20.3 & 18.1 \\
\hline
\end{tabular}

$\bar{x}$ Percent biomass loss to take-all infection compared with uninoculated plants.

y Percent biomass loss to take-all infection was calculated for each plant accession as: [(weight of uninoculated plants) - (weight of inoculated plants)] $* 100 \% /$ (weight of uninoculated plants).

z Values are means of four replications. Entries within a column that do not share a common letter were significantly different in a mean separation test using Fisher's protected LSD $(P<0.05)$. 
Coker $9663(P>0.05)$. However, by 30 May, five of these entries had severity scores significantly less than Coker 9663. The remaining two entries were similar to Coker 9663 at this rating date. Only one entry (PI 386150) was grouped with Larned by the second date.

In 2004, BYD pressure was more severe than the previous year as evidenced by a nearly $50 \%$ increase in symptomatic plants observed for the susceptible control (Larned) at the second sampling date. At the first sampling date of 2004, all 10 of the grasses had incidence scores that were not significantly different from Coker 9663. However, by 28 May, seven of these entries had incidence scores significantly less than Coker 9663. The remaining entries were similar to Coker 9663 at this rating date.
Wheat streak mosaic. Wheat streak mosaic symptoms were evident on all plants of the susceptible wheat control 2180, and ELISA absorbance ratings were positive and exceeded the healthy, mock-inoculated control by greater than twofold in both experiments (Table 5). Symptoms were more ambiguous on the other grasses, and WSM ELISA absorbance ratings were less consistent compared with 2180 .

In the first experiment, WSM ELISA absorbance ratings for some of the grasses were barely $2 \times$ greater than for the healthy control (data not shown), whereas values for the susceptible control were consistently $3 x$ to $4 \times$ higher. Further, none of the grasses that tested positive did so in every replicate, unlike the susceptible control (Table 5). Five of the 10 grasses tested positive for WSM in at

Table 4. Reaction of perennial grass accessions to barley yellow dwarf (BYD)

\begin{tabular}{|c|c|c|c|c|}
\hline \multirow[b]{3}{*}{ Entry } & \multicolumn{4}{|c|}{ BYD incidence i $^{y}$} \\
\hline & \multicolumn{2}{|c|}{ Exp. 1 (2003) } & \multicolumn{2}{|c|}{ Exp. 2 (2004) } \\
\hline & 15 May & 30 May & 20 May & 28 May \\
\hline PSR-1 & $0.0 \mathrm{c}^{\mathrm{z}}$ & $1.0 \mathrm{~g}$ & $2.6 \mathrm{def}$ & $1.4 \mathrm{e}$ \\
\hline PSR-2 & $12.8 \mathrm{~b}$ & $28.0 \mathrm{bc}$ & $7.0 \mathrm{bcd}$ & $13.0 \mathrm{bc}$ \\
\hline BFPMC1 & $0.0 \mathrm{c}$ & $0.0 \mathrm{~g}$ & $4.4 \mathrm{~b}-\mathrm{f}$ & $3.2 \mathrm{e}$ \\
\hline TA 12252 & $0.0 \mathrm{c}$ & $0.0 \mathrm{~g}$ & $0.3 \mathrm{f}$ & $5.0 \mathrm{de}$ \\
\hline PI 386149 & $8.8 \mathrm{bc}$ & $15.0 \mathrm{de}$ & $5.3 \mathrm{~b}-\mathrm{e}$ & $12.3 \mathrm{~cd}$ \\
\hline PI 386150 & $24.4 \mathrm{a}$ & $32.0 \mathrm{ab}$ & $9.2 \mathrm{~b}$ & $16.0 \mathrm{bc}$ \\
\hline PI 386156 & $15.2 \mathrm{~b}$ & $23.4 \mathrm{~cd}$ & $7.6 \mathrm{bc}$ & $16.4 \mathrm{bc}$ \\
\hline Permontra & $0.0 \mathrm{c}$ & $4.0 \mathrm{fg}$ & $0.8 \mathrm{ef}$ & $5.0 \mathrm{de}$ \\
\hline PI 223231 & $0.0 \mathrm{c}$ & $0.7 \mathrm{~g}$ & $3.2 \mathrm{c}-\mathrm{f}$ & $2.2 \mathrm{e}$ \\
\hline PI 502359 & $1.0 \mathrm{c}$ & $1.6 \mathrm{~g}$ & $4.6 \mathrm{~b}-\mathrm{f}$ & $4.8 \mathrm{e}$ \\
\hline Coker 9663 (control) & $2.0 \mathrm{c}$ & $11.2 \mathrm{ef}$ & $5.0 \mathrm{~b}-\mathrm{f}$ & $19.6 \mathrm{~b}$ \\
\hline Larned (control) & $24.6 \mathrm{a}$ & $39.0 \mathrm{a}$ & $22.2 \mathrm{a}$ & $54.0 \mathrm{a}$ \\
\hline $\operatorname{LSD}(P<0.05)$ & 9.0 & 8.4 & 4.9 & 7.3 \\
\hline
\end{tabular}

y Percent plants showing leaf symptoms of BYD.

z Values are means of five replications. Entries within a column that do not share a common letter were significantly different in a mean separation test using Fisher's protected LSD $(P<0.05)$.

Table 5. Reaction of perennial grass accessions to wheat streak mosaic

\begin{tabular}{|c|c|c|c|}
\hline & $\begin{array}{c}\text { No. of positive plants/ } \\
\text { total replicates }^{w}\end{array}$ & $\begin{array}{c}\text { ELISA absorbance } \\
\text { readings }^{x, y}\end{array}$ & \\
\hline Entry & Exp. 1 & Exp. 2 & Phenotype $^{\mathrm{z}}$ \\
\hline PSR-1 & $1 / 5$ & $0.519 \mathrm{bc}$ & $\mathrm{S}$ \\
\hline PSR-2 & $5 / 5$ & $0.591 \mathrm{~b}$ & $\mathrm{~S}$ \\
\hline BFPMC1 & $0 / 5$ & $0.215 \mathrm{~d}$ & $\mathrm{R}$ \\
\hline TA 12252 & $0 / 5$ & $0.185 \mathrm{~d}$ & $\mathrm{R}$ \\
\hline PI 386149 & $3 / 5$ & $0.402 \mathrm{c}$ & $\mathrm{S}$ \\
\hline PI 386150 & $4 / 5$ & $0.424 \mathrm{c}$ & $\mathrm{S}$ \\
\hline PI 386156 & $4 / 5$ & $0.491 \mathrm{bc}$ & $\mathrm{S}$ \\
\hline Permontra & $0 / 5$ & $0.209 \mathrm{~d}$ & $\mathrm{R}$ \\
\hline PI 223231 & $0 / 5$ & $0.206 \mathrm{~d}$ & $\mathrm{R}$ \\
\hline PI 502359 & $0 / 5$ & $0.201 \mathrm{~d}$ & $\mathrm{R}$ \\
\hline 2180 (inoculated control) & $5 / 5$ & $0.981 \mathrm{a}$ & $\mathrm{S}$ \\
\hline 2180 (uninoculated control) & $0 / 5$ & $0.195 \mathrm{~d}$ & $\ldots$ \\
\hline LSD $(P<0.05)$ & $\ldots$ & 0.154 & $\ldots$ \\
\hline
\end{tabular}

${ }^{\mathrm{w}}$ Enzyme-linked immunosorbent assay (ELISA) absorbance readings were qualitative and considered positive (susceptible) if values were twofold greater than those of the healthy check.

${ }^{x}$ ELISA absorbance readings were quantitative in that assays were carried out one block at a time and absorbencies were read every $15 \mathrm{~min}$ after the addition of substrate until values passed 2.000. Values were considered positive (susceptible) if significantly higher than the healthy control $(P<0.05)$.

y Values are means of five replications and ELISA absorbance readings at 15 and 30 min after addition of the substrate. Entries within a column that do not share a common letter were significantly different in a mean separation test using Fisher's protected LSD $(P<0.05)$.

${ }^{\mathrm{z}}$ A line was considered susceptible $(\mathrm{S})$ if a positive reading was expressed in one or more replicates, or resistant $(\mathrm{R})$ if all readings were negative.

least one replicate and were considered susceptible.

In the second experiment, WSM ELISA values were low when compared with the susceptible control and sometimes were near the cut-off point (two times the healthy control value) for designation as clearly positive. ELISA absorbance ratings at 15 and 30 min were averaged for analysis in the second experiment since the results did not differ at individual rating times. Values for the susceptible control were significantly $(P<0.05)$ higher than for all other entries. The five susceptible grasses identified in the first experiment had values significantly higher than the healthy control and the remaining five grasses. But ELISA absorbance ratings for the susceptible grasses were significantly lower than for the susceptible control (2180).

\section{DISCUSSION}

Several of the grasses were resistant to tan spot, BYD, and WSM under our screening conditions. Indeed, the wild grasses and perennial donors Thinopyrum intermedium (PI 223231), including BFPMC1, T. ponticum (PI 502359), and $S$. montanum (TA 12252), in addition to Permontra, a tetraploid perennial rye, were highly resistant to all three diseases as evidenced by similar or fewer disease symptoms compared with the resistant or noninoculated controls. However, all 10 grass accessions exhibited moderate to high proportional biomass loss to take-all in at least one of the two experiments.

The three triticale accessions (PI 386149, PI 386150, and PI 386156), all derived from Triticum aestivum $\times S$. montanum hybrids, were moderately susceptible to tan spot as severity scores were significantly lower than the susceptible wheat control, but higher than all other entries including the resistant wheat control. This agrees with earlier work in which moderate susceptibility was reported for normal triticale accessions derived from wheat $x$ $S$. cereale hybrids (34). All other entries were highly resistant to tan spot, and severity values were either similar to or lower than the resistant wheat control.

All grasses were rated as resistant to BYD in the second experiment when disease pressure was high, but three grass accessions (PSR-2, PI 386150, and PI 386156) had substantially higher incidence values than the resistant wheat control in the first experiment when disease pressure was lower. Indeed, incidence of BYD for PI 386150 was similar to the susceptible control in the first experiment, but considerably lower in the second. Resistance to BYD has been previously reported in Canada wild rye (Elymus canadensis) $(13,20)$, but not in $S$. montanum as was observed in this study. Resistance was not consistently expressed by the triticale accessions, but the BYD reactions of their $S$. montanum 
parents (which were not TA 12252) are unknown. Thinopyrum accessions PI 223231, PI 502359, and BFPMC1 were also resistant to BYD, which agrees with previous work $(15,24,26)$. Natural inoculum was used in these tests, which may have included a variety of BYDV strains because of proximity to both wheat fields and tallgrass prairie. The dominant BYDV strains differed among prairie grass species in Kansas (16), and it will be useful to determine in future studies whether perennial grains also differ in their reaction to a range of BYDV strains.

Results of WSM ELISA tests indicated that five of the 10 grasses were susceptible to WSM, including the perennial wheat lines and triticales. However, clear disease symptoms were not always present on these entries, whereas mosaic patterns were visibly striking on the susceptible wheat control. Leaf chlorosis, ranging from dashes to longitudinal streaks, and stunted plants are typical (42), although symptoms can vary according to isolate, temperature, and host (43). ELISA absorbance readings were at least twofold greater for these lines than the healthy wheat control for many of the replicates, although they were statistically lower than the susceptible wheat control. Further, results were variable and not all susceptible plants tested positive for WSM in every replicate, although the inoculated control was consistently positive. This may be a result of heterogeneity within populations or genetic instability $(9,25)$. These entries, therefore, appear to be susceptible to WSM, but carry lower virus titer than wheat. PI 223231, PI 502359, and TA 12252 were resistant to WSM, which is consistent with previous work $(9,14,15,28)$.

Resistance to the wheat curl mite, the vector of WSM, is another approach for limiting the spread of WSMV and was first identified by Andrews and Slykhuis (1) in hybrids derived from crosses of Triticum aestivum $\times A$. elongatum and A. intermedium. Resistance gene Wsml from T. intermedium confers resistance to WSM and to wheat curl mite colonization $(14,15)$. Although this study did not test for mite resistance, the adaptive ability of wheat curl mites may limit the value of this type of resistance in a wheat monoculture.

All of the grasses exhibited substantial biomass loss to take-all in at least one of the two experiments. In both experiments, TA 12252 (perennial rye) and Permontra were more resistant to take-all as evidenced by less proportional biomass loss than the susceptible wheat control, although in the first experiment they suffered losses greater than $60 \%$. For both entries, biomass losses due to take-all were less than $10 \%$ in the second experiment. Additionally, PI 386149 appears moderately resistant to take-all compared with the susceptible wheat control, although losses of 61.5 and $39.0 \%$ were reported in experiments one and two, respectively.

Take-all damage decreases at temperatures above $26.5^{\circ} \mathrm{C}$ (W. W. Bockus, personal observation), so it is possible that differences in greenhouse conditions could explain the different results in the two take-all experiments. Temperature does not provide a clear explanation, however, since the first experiment was performed during late fall when the consistently higher temperatures known to reduce take-all severity were not observed.

The take-all pathogen is a weak competitor in communities of saprophytes in plant residue (2). The buildup of antagonistic soil microbes in annual wheat fields, with fluorescent pseudomonads specifically implicated worldwide, is associated with take-all decline, although this phenomenon can take more than 6 years to develop (44). Even in the absence of resistance, take-all would most likely decline as well in a perennial grain crop. For example, as bacterial populations change within brown patches of perennial turfgrass infected by G. graminis var. avenae, take-all declines and susceptible host species can recolonize formerly diseased areas (39).

The ability of soils to generally suppress soilborne diseases is often enhanced by the addition of organic matter, the buildup of soil fertility, and certain agronomic practices such as crop rotation, cover crops, and organic farming $(38,44)$. Thick, healthy perennial grass stands, like those established on Conservation Reserve Program land, restore soil nutrient levels and organic matter (19), increase soil quality (21), and increase soil microbial activity (21) and diversity (31), all of which may shift the competition between microbes and compromise the dominance or fitness of those pathogenic on the host. Some of the dominant perennial grasses of the native tall and short grass prairies have no resistance to take-all (C. Cox and $\mathrm{K}$. Garrett, unpublished data), although it may be that the established microbial community in the prairie ecosystem would have a suppressive effect on takeall.

Resistance to barley yellow dwarf, tan spot, and wheat streak mosaic was identified in several grasses potentially important for the development of perennial grains. None, however, appeared highly resistant to take-all. Although the primary objective of this work was to identify potential sources of resistance for development of perennial grain cultivars, susceptible lines may be useful as controls in future ecological studies and as parental lines in genetic studies. Further study is warranted that explores the performance of the resistance sources under natural disease epiphytotics and the introgression of these resistance sources into perennial and annual grain cultivars adapted to the central Great Plains.
ACKNOWLEDGMENTS

We thank R. L. Bowden, B. Gill, and Plant Disease reviewers for comments that improved this manuscript. This work was supported by a graduate fellowship from The Land Institute awarded to C. M. Cox, by USDA Grant 2002-34103-11746, by NSF Grant DEB-0130692, and by Regional Research Funds from North Central Project NC-125. This is Kansas State Experiment Station Contribution No. 05-195-J.

\section{LITERATURE CITED}

1. Andrews, J. E., and Slykhuis, J. T. 1956. Reaction of winter wheat varieties and Triticum $\times$ Agropyron hybrids when inoculated with wheat streak mosaic virus by the mite vector Aceria tulipae Keifer. Plant Dis. Rep. 40:513516.

2. Asher, M. J. C., and Shipton, P. J., eds. 1981. Biology and Control of Take-all. Academic Press, London.

3. Bockus, W. W., Appel, J. A., Bowden, R. L., Fritz, A. K., Gill, B. S., Martin, T. J., Sears, R. G., Seifers, D. L., Brown-Guedira, G. L., and Eversmeyer, M. G. 2001. Success stories: Breeding for wheat disease resistance in Kansas. Plant Dis. 85:453-461.

4. Bowden, R., Shroyer, J., Roozeboom, K., Claassen, M., Evans, P., Gordon, B., Heer, B., Janssen, K., Long, J., Martin, J., Schlegel, A., Sears, R., and Witt, M. 2001. Performance of wheat variety blends in Kansas. Kansas State Univ. Agric. Ext. Bull. 128.

5. Ciuffetti, L. M., Francl, L. J., Ballance, G. M., Bockus, W. W., Lamari, L., Meinhardt, S. W., and Rasmussen, J. B. 1998. Standardization of toxin nomenclature in the Pyrenophora triticirepentis/wheat interaction. Can. J. Plant Pathol. 20:421-424.

6. Clark, M. F., and Adams, A. N. 1977. Characteristics of the microplate method of enzymelinked immunosorbent assay for the detection of plant viruses. J. Gen. Virol. 34:475-483.

7. Cox, C. M., Garrett, K. A., and Bockus, W. W. 2005. Meeting the challenge of disease management in perennial grain cropping systems. Ren. Agric. Food Sys. 20:15-24.

8. Cox, C. M., Garrett, K. A., Bowden, R. L., Fritz, A. K., Dendy, S. P., and Heer, W. F. 2004. Cultivar mixtures for the simultaneous management of multiple diseases: Tan spot and leaf rust of wheat. Phytopathology 94:961-969.

9. Cox, C. M., Murray, T. D., and Jones, S. S 2002. Perennial wheat germ plasm lines resistant to eyespot, Cephalosporium stripe, and wheat streak mosaic. Plant Dis. 86:1043-1048.

10. Cox, T. S., Bender, M., Picone, C., Van Tassel, D. L., Holland, J. B., Brummer, E. C., Zoeller, B. E., Paterson, A. H., and Jackson, W. 2002. Breeding perennial grain crops. Crit. Rev. Crop Sci. 21:59-91.

11. DeHaan, L. R., Van Tassel, D. L., and Cox, T. S. 2005. Perennial grain crops: A synthesis of ecology and plant breeding. Ren. Agric. Food Sys. 20:5-14.

12. Dinnes, D. L., Karlen, D. L., Jaynes, D. B., Kaspar, T. C., Hatfield, J. L., Colvin, T. S., and Cambardella, C. A. 2002. Nitrogen management strategies to reduce nitrate leaching in tile-drained Midwestern soils. Agron. J. 94:153-171.

13. Edwards, M. C., Timian, R. G., and Joppa, L. R. 1988. Elymus sp. as sources of resistance to barley yellow dwarf virus. (Abstr.) Phytopathology 78:1584.

14. Friebe, B., Gill, K. S., Tuleen, N. A., and Gill, B. S. 1996. Transfer of wheat streak mosaic virus resistance from Agropyron intermedium into wheat. Crop Sci. 36:857-861.

15. Friebe, B., Jiang, J., Raupp, W. J., McIntosh, R. A., and Gill, B. S. 1996. Characterization of wheat-alien translocations conferring resistance to diseases and pests: Current status. Euphytica 91:59-87. 
16. Garrett, K. A., Dendy, S. P., Power, A. G., Blaisdell, G. K., Alexander, H. M., and McCarron, J. K. 2004. Barley yellow dwarf disease in natural populations of dominant tallgrass prairie species in Kansas. Plant Dis. 88:574.

17. Garrett, K. A., and Mundt, C. C. 1999. Epidemiology in mixed host populations. Phytopathology 89:984-990.

18. Garrett, K. A., and Mundt, C. C. 2000. Effects of planting density and the composition of wheat cultivar mixtures on stripe rust: An analysis taking into account limits to the replication of controls. Phytopathology 90:13131321.

19. Gebhart, D. L., Johnson, H. B., Mayeux, H. S., and Polley, H. W. 1994. The CRP increases soil organic carbon. J. Soil Water Conserv. 49:488-492.

20. Griesbach, J. A., Steffenson, B. J., Brown, M. P., Falk, B. W., and Webster, R. K. 1990. Infection of grasses by barley yellow dwarf viruses in California. Crop Sci. 30:1173-1177.

21. Huggins, D. R., Allen, D. L., Gardner, J. C., Karlen, D. L., Bezdicek, D. F., Rosek, M. J., Alms, M. J., Flock, M., Miller, B. S., and Staben, M. L. 1997. Enhancing carbon sequestration in CRP-managed land. Pages 323-334 in: Management of Carbon Sequestration in Soil. R. Lal, J. M. Kimble, R. F. Follett, and B. A. Stewart, eds. CRC, Boca Raton, FL.

22. Huggins, D. R., Randall, G. W., and Russelle, M. P. 2001. Subsurface drain losses of water and nitrate following conversion of perennials to row crops. Agron. J. 93:477-486.

23. Jackson, W., and Jackson, L. L. 1999. Developing high seed yielding perennial polycultures as a mimic of mid-grass prairie. In: Agriculture as a Mimic of Natural Ecosystems. E. C. Lefroy, R. J. Hobbs, M. H. O'Connor, and J. S. Pate, eds. Kluwer, Dordrecht, The Netherlands.

24. Jones, S. S., Murray, T. D., and Allan, R. E. 1995. Use of alien genes for the development of disease resistance in wheat. Annu. Rev. Phytopathol. 33:429-443.

25. Jones, T. A., Zhang, X. Y., and Wang, R. C. 1999. Genome characterization of MT-2 perennial and OK-906 annual wheat $\times$ intermediate wheatgrass hybrids. Crop Sci. 39:1041-1043.

26. Juahar, P. P., and Peterson, T. S. 1996. Thinopyron and Lophopyrum as sources of genes for wheat improvement. Cereal Res. Commun. 24:15-21.

27. Martin, T. J. 1978. Procedures for evaluating wheat streak mosaic virus resistance. Plant Dis. Rep. 62:1062-1066.

28. McKinney, H. H., and Sando, W. J. 1951. Susceptibility and resistance to the wheat streak mosaic virus in the genera Triticum, Agropyron, Secale, and certain hybrids. Plant Dis. Rep. 35:476-478.

29. Moffat, A. S. 1996. Higher yielding perennials point the way to new crops. Science 274:14691470 .

30. Mundt, C. C. 2002. Use of multiline cultivars and cultivar mixtures for disease management. Annu. Rev. Phytopathol. 40:381-410.

31. Neher, D. A. 1995. Biological diversity in soils of agricultural and natural ecosystems. Pages 55-71 in: Exploring the Role of Diversity in Sustainable Agriculture. R. Olson, C. Francis, and S. Kaffka, eds. American Society of Agronomy, Crop Science Society of America, Soil Science Society of America, Madison, WI.

32. Pimental, D., McLaughlin, L., Zepp, A., Lakitan, B., Kraus, T., Kleinman, P., Vancini, F., Roach, W. J., Graap, E., Keeton, W. S., and Selig, G. 1991. Environmental and economic impacts of reducing US agricultural pesticide use. Pages 679-718 in: CRC Handbook of Pest Management in Agriculture, Vol. 1. D. Pimentel and A. A. Hanson, eds. CRC Press, Boca Raton, FL.

33. Pimm, S. L. 1997. In search of perennial solutions. Nature 389:126-127.

34. Prescott, J. M., Burnett, P. A., Saari, E. E., Ranson, J., Bowman, J., de Milliano, W., Singh, R. P., and. Bekele, G., eds. 1986. Wheat Diseases and Pests: A Guide for Field Identification. International Maize and Wheat Improvement Center, Mexico, D.F., Mexico.

35. Rabalais, N. N., Turner, R. E., Dortch, Q., Dubravko, J., Bierman, V. J., Jr., and Wiseman, W. J., Jr. 2002. Nutrient-enhanced productivity in the northern Gulf of Mexico: Past, present, and future. Hydrobiologia 475/476:39-63.

36. Randall, G. W., Huggins, D. R., Russelle, M.
P., Fuchs, D. J., Nelson, W. W., and Anderson, J. L. 1997. Nitrate losses through subsurface tile drainage in Conservation Reserve Program, alfalfa, and row crop systems. J. Environ. Qual. 26:1240-1247.

37. Raymond, P. J., Bockus, W. W., and Norman B. L. 1985. Tan spot of winter wheat: Procedures to determine host response. Phytopathology 75:686-690.

38. Rovira A. D., Wildermuth, G. B. 1981. The nature and mechanisms of suppression. Pages 385-415 in: Biology and Control of Take-all. M. J. C. Asher and P. Shipton, eds. Academic Press, London, England.

39. Sarniguet, A., and Lucas, P. 1992. Evaluation of populations of fluorescent pseudomonads related to decline of take-all patch on turfgrass. Plant Soil 145:11-15.

40. Scheinhost, P. L., Lammer, D. L., Cai, X., Murray, T. D., and Jones, S. S. 2001. Perennial wheat: The development of a sustainable cropping system for the U.S. Pacific Northwest. Am. J. Altern. Agric. 16:147-151.

41. Seifers, D. L., Martin, T. J., Harvey, T. L., and Gill, B. S. 1995. Temperature sensitivity and efficacy of wheat streak mosaic virus resistance derived from Agropyron intermedium. Plant Dis. 79:1104-1106.

42. Slykhuis, J. T., and Bell, W. 1965. Differentiation of Agropyron mosaic, wheat streak mosaic, and a hitherto unrecognized Hordeum mosaic virus in Canada. Can. J. Bot. 44:1191 1208

43. Staples, R., and Allington, W. B. 1956. Streak mosaic of wheat in Nebraska and its control. Neb. Agric. Exp. Stn. Res. Bull. 178.

44. Weller, D. M., Raaijmakers, J. M. McSpadden-Gardener, B. B., and Thomashow, L. S 2002. Microbial populations responsible for specific soil suppressiveness to plant pathogens. Annu. Rev. Phytopathol. 40:309-348.

45. Wiese, M. V. 1987. Compendium of Wheat Diseases. American Phytopathological Society, St. Paul, MN.

46. Zhu, Y., Hairu, C., Fan, J., Wang, Y., Li, Y. Chen, J., Fan, J., Yang, S., Hu, L., Leung, H. Mew, T. W., Teng, P. S., Wang, Z., and Mundt, C. C. 2000. Genetic diversity and disease control in rice. Nature 406:718-722. 